\title{
Statiatistika
}

p-ISSN 1979 - 3693

e-ISSN 2477 - 0647

MEDIA STATISTIKA 9(2) 2016: 119-132

http://ejournal.undip.ac.id/index.php/media_statistika

\section{KAJIAN AKTIVITAS EKONOMI LUAR NEGERI INDONESIA TERHADAP PERTUMBUHAN EKONOMI INDONESIA PERIODE 1998-2014}

\author{
Ryan Hawari , Fitri Kartiasih ${ }^{2}$ \\ ${ }^{1,2}$ Sekolah Tinggi Ilmu Statistik, Jakarta \\ e-mail: ${ }^{1}$ ryan.hawari@bps.go.id; ${ }^{2}$ fkartiasih@stis.ac.id
}

DOI: 10.14710/medstat.9.2.119-132

\begin{abstract}
Indonesia is a developing country which adopts an "open economic". That caused Indonesia economic is strongly influenced by factors that come from outside of Indonesia. External factors in this research is referred to foreign debt, foreign direct investment, trade openness and exchange rate of rupiah with USD. The analytical method in this research used Vector Error Correction Model (VECM) which will focused on Impulse Response Function (IRF) and Forecast Error Variance Decomposition (FEVD). Based on result of IRF, exchange rate had a positive effect to economic growth, while foreign debt, foreign direct investment and trade openness had a negative effect to economic growth. Based on result of FEVD, shock on economic growth in Indonesia affected by economic growth itself $(43.21 \%)$, followed by foreign debt (26.30\%), trade openness $(14.16 \%)$, foreign direct investment (8.29\%) and exchange rate (8.04\%)
\end{abstract}

Keywords: economic growth, trade openness, VECM, IRF, FEVD

\section{PENDAHULUAN}

Pertumbuhan ekonomi merupakan salah satu indikator yang sangat penting dalam melakukan analisis tentang pembangunan ekonomi di suatu negara. Pertumbuhan ekonomi menjadi penting karena dapat menunjukkan sejauh mana aktivitas perekonomian akan menghasilkan tambahan pendapatan bagi masyarakatnya dalam periode waktu tertentu. Secara umum, keberhasilan pembangunan ekonomi suatu negara dapat diukur dan digambarkan oleh laju pertumbuhan ekonominya (Mankiw, 2006).

Indonesia pernah memiliki suatu kondisi perekonomian yang cukup menjanjikan pada tahun 1980-an sampai pertengahan tahun 1990-an. Berdasarkan data Badan Pusat Statistik (BPS), pertumbuhan ekonomi Indonesia terus mengalami peningkatan dari tahun 1986 sampai dengan tahun 1989, yakni masing-masing 5.9\% pada tahun 1986 dan terus meningkat menjadi 7.5\% pada tahun 1989. Namun, pada tahun 1990 dan 1991 pertumbuhan ekonomi Indonesia berada di angka 7\%. Kemudian pada tahun 1992, 1993, 1994, 1995, dan 1996, masing-masing tingkat pertumbuhan ekonominya adalah sebesar $6.2 \%, 5.8 \%, 7.2 \%, 6.8 \%$, dan $5.8 \%$.

Menurut data BPS, pada tahun 1997 kuartal ketiga pertumbuhan ekonomi masih mengalami pertumbuhan yang positif yaitu sebesar 3.4\%. Sementara pada kuartal terakhir 
tahun 1997, merupakan puncak ambruknya perekonomian di Indonesia karena pertumbuhan ekonomi di Indonesia berada di angka 0\%. Pada tahun 1998 pertumbuhan ekonomi terus menurun tajam menjadi minus $7.9 \%$ pada kuartal pertama, minus $16.5 \%$ pada kuartal kedua, minus $17.9 \%$ pada kuartal ketiga dan minus $17.7 \%$ pada kuartal terakhir.

Indonesia merupakan salah satu negara yang menganut sistem perekonomian terbuka. Hal itu ditunjukkan dengan trade openness Indonesia yang tergolong cukup besar yaitu 41.52\% pada tahun 2014. Tingginya trade openness tersebut berimbas kepada neraca perdagangan Indonesia. Tercatat bahwa pada tahun 2014, neraca perdagangan Indonesia mengalami defisit sebesar 23,403.8 miliar rupiah. Di samping itu, utang luar negeri pemerintah Indonesia juga terus meningkat dari tahun ke tahun. Utang luar negeri Indonesia meningkat dari 266,120 juta USD pada tahun 2013 menjadi 292,579 juta USD pada tahun 2014. Dalam kondisi tersebut, pertumbuhan ekonomi menurun dari 5.7\% pada tahun 2013 menjadi 5.01\% pada tahun 2014.

Berdasarkan hal tersebut, aktivitas-aktivitas ekonomi luar negeri Indonesia diduga mempunyai pengaruh terhadap pertumbuhan ekonomi. Namun belakangan terdapat banyak kontradiksi dalam teori maupun penerapannya dalam perekonomian di Indonesia. Dengan demikian, peneliti merasa penting untuk membahas tentang hubungan aktivitas ekonomi luar negeri Indonesia terhadap pertumbuhan ekonomi di Indonesia.

Oleh sebab itu, penelitian ini memfokuskan pada aktivitas ekonomi luar negeri di Indonesia periode 1998-2014. Aktivitas ekonomi luar negeri dalam penelitian ini adalah nilai tukar rupiah, trade opennes, penanaman modal asing dan utang luar negeri Indonesia. Dengan demikian, tujuan dari penelitian ini adalah untuk menggambarkan kondisi aktivitas ekonomi luar negeri di Indonesia pada periode 1998-2014 serta menganalisis pengaruh dan kontribusi dari utang luar negeri, Penanaman Modal Asing (PMA), trade openness dan nilai tukar rupiah terhadap pertumbuhan ekonomi di Indonesia.

\section{KAJIAN PUSTAKA DAN METODOLOGI}

Sukirno (2006) menyatakan bahwa pertumbuhan ekonomi merupakan suatu ukuran kuantitatif yang dapat menggambarkan perkembangan suatu perekonomian dalam suatu tahun tertentu apabila dibandingkan dengan tahun sebelumnya. Perkembangan tersebut selalu dinyatakan dalam bentuk persentase perubahan pendapatan nasional pada suatu tahun tertentu dibandingkan dengan tahun sebelumnya.

Menurut Purwanto (2011), keterbukaan ekonomi memberi keuntungan bagi semua negara yang terlibat didalamnya. Keuntungan dari keterbukaan perdagangan diantaranya berupa pembukaan akses pasar yang lebih luas, pencapaian tingkat efisiensi dan daya saing ekonomi yang lebih tinggi, serta peluang penyerapan tenaga kerja yang lebih besar. Dengan menerapkan keterbukaan ekonomi, perekonomian di negara tersebut diharapkan akan menjadi lebih baik. Dengan kata lain, aktivitas ekonomi luar negeri Indonesia akan sangat mempengaruhi pertumbuhan ekonomi Indonesia. Adapun aktivitas ekonomi luar negeri dalam penelitian ini adalah:

1. Utang luar negeri

2. Penanaman modal asing di Indonesia

3. Nilai tukar rupiah

4. Trade openness 
Penelitian ini menggunakan data sekunder yang diperoleh dari Badan Pusat Statistik (BPS), Badan Koordinasi Penanaman Modal (BKPM) dan Bank Indonesia (BI). Data yang digunakan merupakan data triwulanan dengan periode dari triwulan IV tahun 1998 sampai dengan triwulan IV tahun 2014. Data-data tersebut adalah Produk Domestik Bruto (PDB) riil Indonesia, total ekspor dan impor Indonesia, total utang luar negeri Indonesia, jumlah penanaman modal asing di Indonesia dan nilai tukar rupiah.

Analisis yang digunakan dalam penelitian ini adalah analisis deskriptif dan analisis inferensia.analisis deskriptif yang digunakan dengan menggunakan penyajian data melalui grafik. Sedangkan analisis inferensia yang digunakan yaitu analisis time series dengan menggunakan Vector Error Correction Model (VECM).

Model VECM dalam penelitian ini adalah sebagai berikut:

Persamaan jangka panjang:

$$
\begin{aligned}
& \mathrm{GROWTH}_{t}=\beta_{10}+\beta_{11} \mathrm{GROWTH}_{t-1}+\beta_{12} L N_{-} \mathrm{KURS}_{t-1}+\beta_{13} L N_{-} U L N_{t-1}+\beta_{14} \mathrm{TO}_{t-1} \\
& +\beta_{15} L N_{-} P M A_{t-1}+\varepsilon_{1 t} \\
& L N_{-} K_{U R S}=\beta_{20}+\beta_{21} G R O W T H_{t-1}+\beta_{22} L N_{-} K U R S_{t-1}+\beta_{23} L N_{-} U L N_{t-1}+\beta_{24} T O_{t-1} \\
& +\beta_{25} L N_{-} P M A_{t-1}+\varepsilon_{2 t} \\
& L N_{-} U L N_{t}=\beta_{30}+\beta_{31} G R O W T H_{t-1}+\beta_{32} L N_{-} K U R S_{t-1}+\beta_{33} L N_{-} U L N_{t-1}+\beta_{34} T O_{t-1} \\
& +\beta_{35} L N_{-} P M A_{t-1}+\varepsilon_{3 t} \\
& T O_{t}=\beta_{40}+\beta_{41} G R O W T H_{t-1}+\beta_{42} L N_{-} K_{U R S}+\beta_{43} L N_{-} U L N_{t-1}+\beta_{44} T O_{t-1} \\
& +\beta_{45} L N_{-} P M A_{t-1}+\varepsilon_{4 t} \\
& L N_{-} P M A_{t}=\beta_{50}+\beta_{51} G R O W T H_{t-1}+\beta_{52} L N_{-} K U R S_{t-1}+\beta_{53} L N_{-} U L N_{t-1}+\beta_{54} T O_{t-1} \\
& +\beta_{55} L N_{-} P M A_{t-1}+\varepsilon_{5 t}
\end{aligned}
$$

Persamaan jangka pendek:

$$
\begin{aligned}
& \Delta G R O W T H_{t}=\alpha_{10}+\alpha_{11} \Delta G R O W T H_{t-1}+\alpha_{12} \Delta L N_{-} U L N_{t-1}+\alpha_{13} L N_{-} P M A_{t-1} \\
& +\alpha_{14} \Delta T O_{t-1}+\alpha_{15} \Delta L N_{-} K_{U R S}+\alpha_{16} \hat{\varepsilon}_{t-1}+v_{1 t} \\
& \Delta L N_{-} U L N_{t}=\alpha_{20}+\alpha_{21} \Delta G R O W T H_{t-1}+\alpha_{22} \Delta L N_{-} U L N_{t-1}+\alpha_{23} L N_{-} P M A_{t-1} \\
& +\alpha_{24} \Delta T O_{t-1}+\alpha_{25} \Delta L N_{-} K_{U R S}+\alpha_{t-1} \hat{\varepsilon}_{t-1}+v_{2 t} \\
& \Delta L N_{-} P M A_{t}=\alpha_{30}+\alpha_{31} \Delta G R O W T H_{t-1}+\alpha_{32} \Delta L N_{-} U L N_{t-1}+\alpha_{33} L N_{-} P M A_{t-1} \\
& +\alpha_{34} \Delta T O_{t-1}+\alpha_{35} \Delta L N_{-} K U R S_{t-1}+\alpha_{36} \hat{\varepsilon}_{t-1}+v_{3 t} \\
& \Delta T O_{t}=\alpha_{40}+\alpha_{41} \Delta G R O W T H_{t-1}+\alpha_{42} \Delta L N_{-} U L N_{t-1}+\alpha_{43} L N_{-} P M A_{t-1}+\alpha_{44} \Delta T O_{t-1} \\
& +\alpha_{45} \Delta L N_{-} K_{U R S_{t-1}}+\alpha_{46} \hat{\varepsilon}_{t-1}+v_{4 t} \\
& \Delta L N_{-} K_{U R S}=\alpha_{50}+\alpha_{51} \Delta G R O W T H_{t-1}+\alpha_{52} \Delta L N_{-} U L N_{t-1}+\alpha_{53} L N_{-} P M A_{t-1} \\
& +\alpha_{54} \Delta T O_{t-1}+\alpha_{55} \Delta L N_{-} K U R S_{t-1}+\alpha_{56} \hat{\varepsilon}_{t-1}+v_{5 t}
\end{aligned}
$$

dengan

$\alpha_{i 1}, \alpha_{i 2}, \alpha_{i 3}, \alpha_{i 4}, \alpha_{i 5}=$ koefisien jangka pendek 


$$
\begin{array}{ll}
\alpha_{i 6} & =\text { koefisien koreksi } \\
\beta_{i 1}, \beta_{i 2}, \beta_{i 3}, \beta_{i 4} & =\text { koefisien jangka panjang } \\
\alpha_{i 0,} \beta_{i 0} & =\text { konstanta } \\
i & =\text { banyaknya variabel } \\
\hat{\varepsilon}_{t-1} & =\text { Error Correction Term (koefisien kointegrasi) }
\end{array}
$$

Analisis VECM dalam penelitian ini difokuskan pada analisis Impulse Response Function (IRF) dan Forecast Error Decomposition Variance (FEVD). Analisis IRF digunakan untuk mengetahui pengaruh dari satu variabel terhadap impulse pada variabel lain dalam suatu sistem yang melibatkan sejumlah variabel di dalamnya. Analisis FEVD digunakan untuk kontribusi dari suatu variabel terhadap shock pada variabel lain dalam suatu sistem.

\section{HASIL DAN PEMBAHASAN}

Pertumbuhan ekonomi Indonesia dari tahun 1998 sampai dengan tahun 2014 mengalami peningkatan yang cukup signifikan dan dalam beberapa periode terakhir mengalami kestabilan di kisaran 5\% sampai dengan 7\% (Lampiran 2). Di sisi lain, beberapa indikator makro ekonomi Indonesia terus mengalami kemerosotan diantaranya adalah utang luar negeri dan nilai tukar rupiah terhadap USD. Utang luar negeri Indonesia meningkat dari 150,886 juta USD pada akhir tahun 1998 menjadi 292,579 juta USD pada akhir tahun 2014 (Lampiran 3). Nilai tukar rupiah terhadap USD terus terdepresiasi dari Rp 8,025.00 per USD pada akhir tahun 1998 menjadi Rp 12,388.00 per USD pada akhir tahun 2014 (Lampiran 4). Selain itu, penanaman modal asing dan trade openness menunjukkan adanya perbaikan. PMA meningkat dari 1,111.58 juta USD menjadi 6,784.55 juta USD (Lampiran 5) dan trade openness menurun dari 65.33\% menjadi 41.52\% (Lampiran 6).

Hasil pengujian kointegrasi (Lampiran 7) menunjukkan bahwa terdapat hubungan jangka panjang antara variabel-variabel makro ekonomi yang diteliti dengan pertumbuhan ekonomi Indonesia. Persamaan jangka panjang yang diperoleh dapat dituliskan sebagai berikut:

$$
\begin{aligned}
& G R O W T H=-0.150709 * L N_{-} K U R S+0.075779 * L N_{-} U L N-0.075059 * L N_{-} P M A \\
& +0.006700 * \text { TO }-0.011074 * \text { TREND }
\end{aligned}
$$

Dari persamaan tersebut dapat dikatakan bahwa pertumbuhan ekonomi Indonesia dipengaruhi secara positif oleh persentase utang luar negeri Indonesia dan trade openness Indonesia. Sedangkan pertumbuhan ekonomi Indonesia dipengaruhi secara negatif oleh persentase nilai tukar rupiah, persentase penanaman modal asing di Indonesia serta pergerakan trend variabel yang berpengaruh secara signifikan terhadap perubahan pertumbuhan ekonomi Indonesia adalah persentase utang luar negeri Indonesia, persentase penanaman modal asing di Indonesia, trade openness Indonesia dan pergerakan trenderw1. Sedangkan persentase nilai tukar rupiah tidak berpengaruh secara signifikan terhadap perubahan pertumbuhan ekonomi Indonesia.

Hasil estimasi persamaan jangka pendek Vector Error Correction Model (VECM) terhadap pertumbuhan ekonomidapat dituliskan sebagai berikut: 


$$
\begin{aligned}
\Delta \text { GROWTH }_{t}= & 0.019572 *-0.080322 \Delta G R O W T H_{t-1}-0.144463 * \Delta L N_{-} U L N_{t-1} \\
& -0.008170 * \Delta L N_{-} P M A_{t-1}+0.001770 * \Delta T O_{t-1} \\
& +0.008382 * \Delta L N_{-} K_{U R S}-0.417915 * e_{1, t-1}+0.032383 * e_{2, t-1}
\end{aligned}
$$

*) signifikan pada $a=5 \%$

Dalam jangka pendek, pertumbuhan ekonomi di Indonesia saat ini dipengaruhi oleh variabel perubahan persentase total utang luar negeri Indonesia dan perubahan tingkat keterbukaan perdagangan Indonesia pada satu periode sebelumnya. Perubahan tingkat keterbukaan perdagangan Indonesia dan perubahan persentase total utang luar negeri Indonesia pada periode sebelumnya memiliki pengaruh yang signifikan terhadap perubahan pertumbuhan ekonomi di Indonesia saat ini. Sementara itu, variabel perubahan pertumbuhan ekonomi di Indonesia, perubahan persentase nilai tukar rupiah dan perubahan persentase jumlah penanaman modal asing pada satu periode sebelumnya tidak memiliki pengaruh yang signifikan terhadap pertumbuhan ekonomi saat ini.

Perubahan persentase total utang luar negeri Indonesia pada satu periode sebelumnya memiliki pengaruh yang negatif dan signifikan terhadap pertumbuhan ekonomi di Indonesia saat ini. Perubahan persentase total utang luar negeri Indonesia dari satu periode sebelumnya memiliki koefisien sebesar 0.144463 terhadap pertumbuhan ekonomi di Indonesia saat ini. Hal ini berarti jika perubahan total utang luar negeri Indonesia pada satu periode sebelumnya meningkat sebesar 1 persen, maka pertumbuhan ekonomi di Indonesia saat ini akan menurun sebesar 0.144 persen.

Perubahan tingkat keterbukaan perdagangan Indonesia pada satu periode sebelumnya memiliki pengaruh yang positif dan signifikan terhadap pertumbuhan ekonomi di Indonesia saat ini.Perubahan tingkat keterbukaan perdagangan Indonesia dari satu periode sebelumnya memiliki koefisien sebesar 0.00177 terhadap perubahan pertumbuhan ekonomi di Indonesia saat ini. Hal ini berarti jika nilai tukar rupiah pada satu periode sebelumnya meningkat sebesar 1 persen, maka pertumbuhan ekonomi di Indonesia saat ini akan meningkat sebesar 0.002 persen.

Koefisien kointegrasi atau Error Correction Term (ECT) berpengaruh negatif dan signifikan pada model ini. Koefisien kointegrasi menunjukkan perbedaan antara keadaan yang diinginkan (jangka panjang) dengan keadaan yang sebenarnya (jangka pendek) akan disesuaikan menuju ke kondisi keseimbangan. Koefisien kointegrasi dalam model ini adalah sebesar 41.79 persen. Nilai tersebut menunjukkan bahwa pertumbuhan ekonomi akan menyesuaikan sebesar 41.79 persen pada triwulan pertama untuk menuju keseimbangan jangka panjang jika terdapat shock di luar keseimbangannya. Sementara itu, 58.21 persen sisanya akan disesuaikan pada triwulan-triwulan berikutnya.

Impulse Response Function (IRF) berfungsi untuk mengetahui respon dari satu variabel terhadap impulse pada variabel lain dalam suatu sistem yang melibatkan sejumlah variabel di dalamnya. Jika ada suatu reaksi dari salah satu variabel yang menyebabkan impulse pada variabel lain, dapat dikatakan bahwa antar variabel tersebut ada hubungan causality. Dalam penelitian ini, variabel yang difokuskan adalah respon dari pertumbuhan ekonomi terhadap impulse dari masing-masing variabel trade openness, penanaman modal asing, utang luar negeri dan nilai tukar rupiah. 


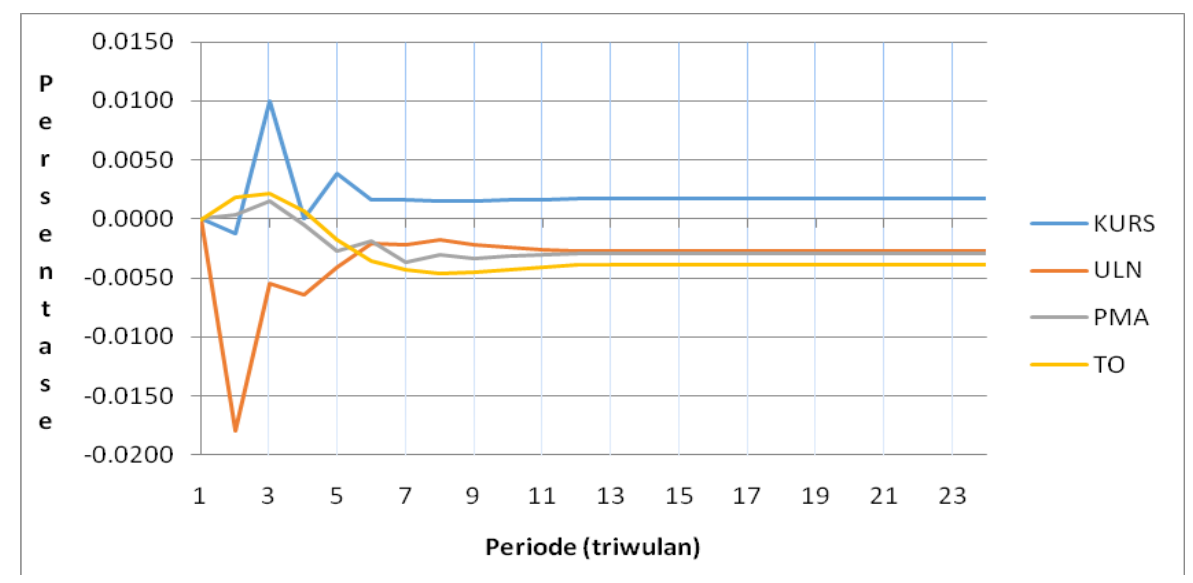

Gambar 1. Respon Pertumbuhan Ekonomi Terhadap Shock Satu Persen Standard Deviation dari Nilai Tukar, Utang Luar Negeri, Penanaman Modal Asing dan Trade Openness

Dari Gambar 1, dapat dilihat berapa periode yang dibutuhkan pertumbuhan ekonomi untuk mencapai kondisi stabil saat adanya shock oleh variabel lain. Dengan kata lain, pengaruh dari variabel-variabel tersebut tidak dirasakan lagi oleh pertumbuhan ekonomi. Ketika terjadi shock pada nilai tukar rupiah, pertumbuhan ekonomi membutuhkan waktu 3 tahun untuk mencapai kondisi keseimbangannya. Sementara itu, ketika terjadi shock pada utang luar negeri maupun penanaman modal asing, pertumbuhan ekonomi membutuhkan waktu 4.5 tahun untuk mencapai kondisi keseimbangannya. Selain itu, ketika terjadi shock pada trade openness, pertumbuhan ekonomi membutuhkan waktu 4 tahun untuk mencapai kondisi keseimbangannya.

Respon dari variabel-variabel tersebut terhadap pertumbuhan ekonomi cukup bervariasi. Pertumbuhan ekonomi merespon positif ketika terjadi shock pada nilai tukar rupiah.Disamping itu, pertumbuhan ekonomi merespon negatif ketika terjadi shock pada utang luar negeri, penanaman modal asing maupun trade openness.

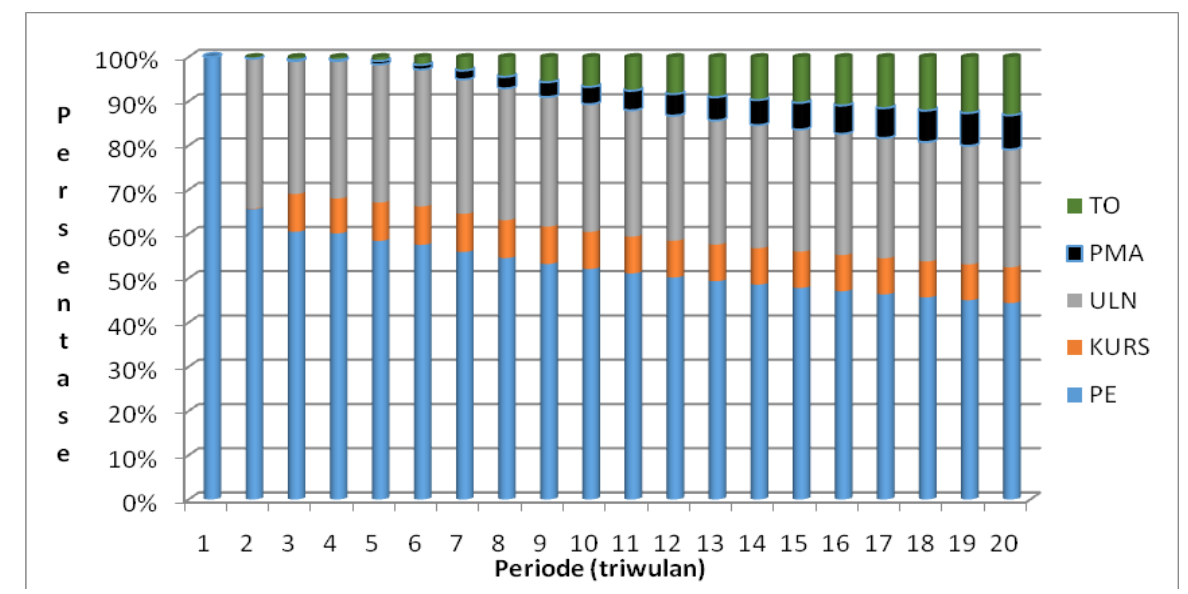

Gambar 2. Kontribusi Shock dari Pertumbuhan Ekonomi, TO, KURS, ULN dan PMA Terhadap Perubahan Pertumbuhan Ekonomi 
Dari Gambar 2, dapat disimpulkan bahwa pada periode pertama yang memberikan shock kepada pertumbuhan ekonomi adalah pertumbuhan ekonomi itu sendiri. Setelah beberapa periode selanjutnya, perubahan pertumbuhan ekonomi di Indonesia dipengaruhi oleh pertumbuhan ekonomi itu sendiri, total utang luar negeri Indonesia, tingkat keterbukaan perdagangan Indonesia, nilai tukar rupiah dan jumlah penanaman modal asing di Indonesia (berdasarkan urutan besarnya kontribusi). Sejak periode ke-22 (periode stabil), pertumbuhan ekonomi di Indonesia akan dipengaruhi oleh pertumbuhan ekonomi itu sendiri, total utang luar negeri Indonesia, tingkat keterbukaan perdagangan Indonesia, jumlah penanaman modal asing di Indonesia dan nilai tukar rupiah (berdasarkan urutan besarnya kontribusi).

\section{KESIMPULAN DAN SARAN}

\subsection{Kesimpulan}

1. Pertumbuhan ekonomi Indonesia dari tahun 1998 sampai dengan tahun 2014 mengalami peningkatan yang cukup signifikan dan dalam beberapa periode terakhir mengalami kestabilan di kisaran 5 persen sampai dengan 7 persen. Di sisi lain, beberapa indikator makroekonomi Indonesia terus mengalami kemerosotan diantaranya adalah utang luar negeri dan nilai tukar rupiah terhadap USD. Utang luar negeri Indonesia meningkat dari 150.886 juta USD pada akhir tahun 1998 menjadi 292,579 juta USD pada akhir tahun 2014. Nilai tukar rupiah terhadap USD terus terdepresiasi dari Rp 8,025.00 per USD pada akhir tahun 1998 menjadi Rp 12,388.00 per USD pada akhir tahun 2014. Selain itu, penanaman modal asing dan trade openness menunjukkan adanya perbaikan. PMA meningkat dari 1,111.58 juta USD menjadi 6,784.55 juta USD dan trade openness menurun dari 65.33 persen menjadi 41.52 persen.

2. Nilai tukar rupiah terhadap USD mempunyai pengaruh yang positif terhadap pertumbuhan ekonomi di Indonesia. Variabel tersebut memiliki hubungan yang sesuai dengan teori dan hipotesis penelitian. Sementara itu, utang luar negeri Indonesia, penanaman modal asing di Indonesia dan trade openness Indonesia mempunyai pengaruh yang negatif terhadap pertumbuhan ekonomi Indonesia. Ketiga variabel tersebut memiliki hubungan yang tidak sesuai dengan teori dan hipotesis penelitian.

3. Pada periode pertama, yang memberikan shock kepada pertumbuhan ekonomi adalah pertumbuhan ekonomi itu sendiri. Setelah beberapa periode selanjutnya, perubahan pertumbuhan ekonomi di Indonesia dipengaruhi oleh pertumbuhan ekonomi itu sendiri, total utang luar negeri Indonesia, tingkat keterbukaan perdagangan Indonesia, nilai tukar rupiah dan jumlah penanaman modal asing di Indonesia (berdasarkan urutan besarnya konstribusi). Sejak periode ke-22 (periode stabil), pertumbuhan ekonomi di Indonesia akan dipengaruhi oleh pertumbuhan ekonomi itu sendiri, total utang luar negeri Indonesia, tingkat keterbukaan perdagangan Indonesia, jumlah penanaman modal asing di Indonesia dan nilai tukar rupiah (berdasarkan urutan besarnya konstribusi).

\subsection{Saran}

1. Untuk dapat mendorong pertumbuhan ekonomi Indonesia, pemerintah Indonesia dapat mengurangi impor yang dilakukan dan berusaha untuk meningkatkan kualitas barang dalam negeri untuk memenuhi kebutuhan masyarakat sehingga akan meningkatkan 
produktivitas ekonomi dalam negeri. Dengan berkurangnya impor yang dilakukan, Indonesia dapat mengurangi beban pada devisa negara yang akan membuat nilai rupiah menjadi lebih kuat.

2. Selain dari perdagangan internasional, pemerintah Indonesia harus memerhatikan sektor penanaman modal asing di Indonesia. Pemerintah Indonesia dapat mengatur dan mengendalikan kegiatan penanaman modal asing di Indonesia agar dapat menguntungkan Indonesia juga. Salah satunya dengan meningkatkan pajak terhadap suatu kegiatan penanaman modal asing di Indonesia, sehingga pendapatan negara akan meningkat dan Indonesia akan lebih merasakan dampak dari penanaman modal asing tersebut.

3. Kontribusi yang besar dari utang luar negeri terhadap pertumbuhan ekonomi di Indonesia (sekitar 30 persen), menyebabkan pemerintah harus lebih memerhatikan penggunaan utang luar negeri tersebut agar dapat dimanfaatkan dengan maksimal untuk meningkatkan perekonomian Indonesia sehingga dapat menjadi stimulus untuk perekonomian di Indonesia. Pemerintah dapat menggunakan utang luar negeri untuk mengembangkan sektor-sektor ekonomi dalam negeri Indonesia. Hal tersebut akan mengurangi ketergantungan Indonesia terhadap luar negeri dan akan membuat Indonesia lebih mandiri dalam menjalankan perekonomiannya.

4. Untuk penelitian lebih lanjut, periode penelitian dapat diperpanjang untuk mendapatkan hasil estimasi yang lebih baik. Selain itu, penelitian selanjutnya juga dapat menggunakan metode peramalan untuk dapat mengestimasi nilai indikator ekonomi luar negeri Indonesia dalam beberapa periode berikutnya.

\section{DAFTAR PUSTAKA}

Mankiw, G.N., 2006, Teori Makro Ekonomi. 6th Edition.Nurmawan [penerjemah], Erlangga, Jakarta.

Purwanto, T., 2011, Analisis Keterbukaan Perdagangan terhadap Pertumbuhan Ekonomi di Negara-negara ASEAN, Tesis, Institut Pertanian Bogor, Tidak dipublikasikan.

Sukirno, S., 2006, Ekonomi Pembangunan: Proses, Masalah dan Dasar Kebijakan, Kencana, Jakarta. 


\section{LAMPIRAN}

Lampiran 1. Kerangka Pikir Penelitian

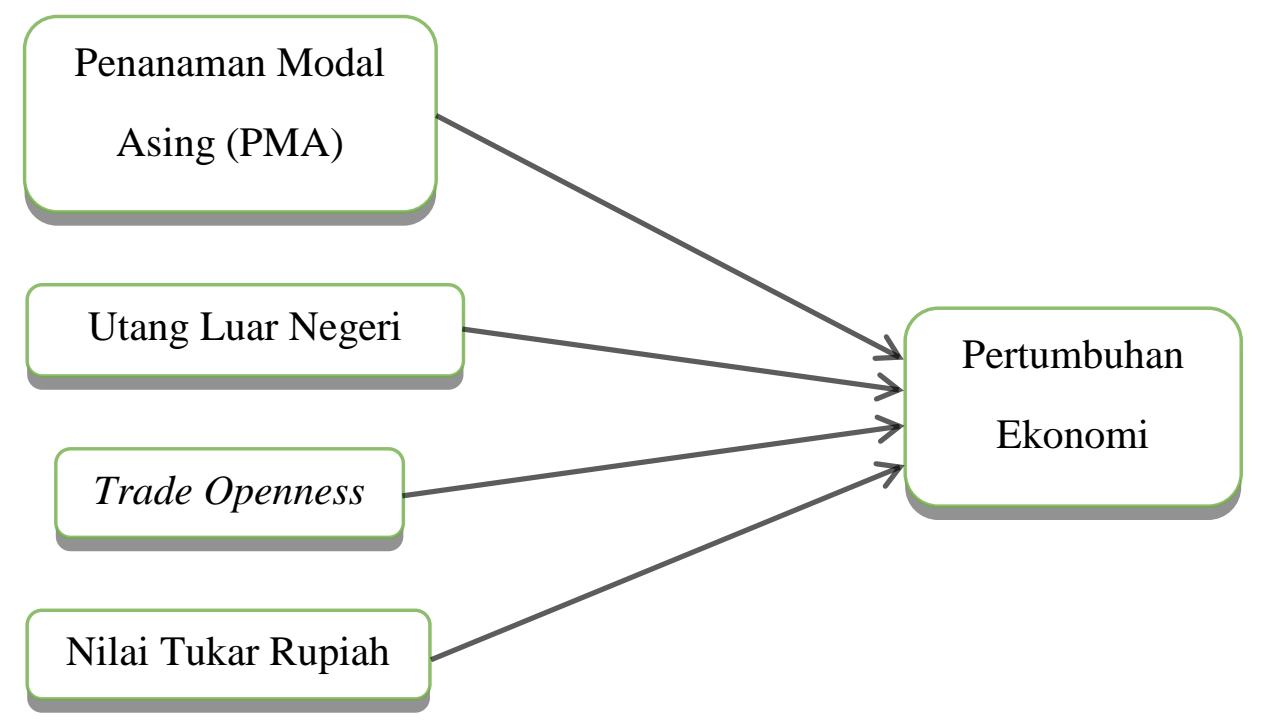

Lampiran 2. Pergerakan Pertumbuhan Ekonomi Indonesia dari Triwulan IV Tahun 1998 sampai Triwulan IV Tahun 2014

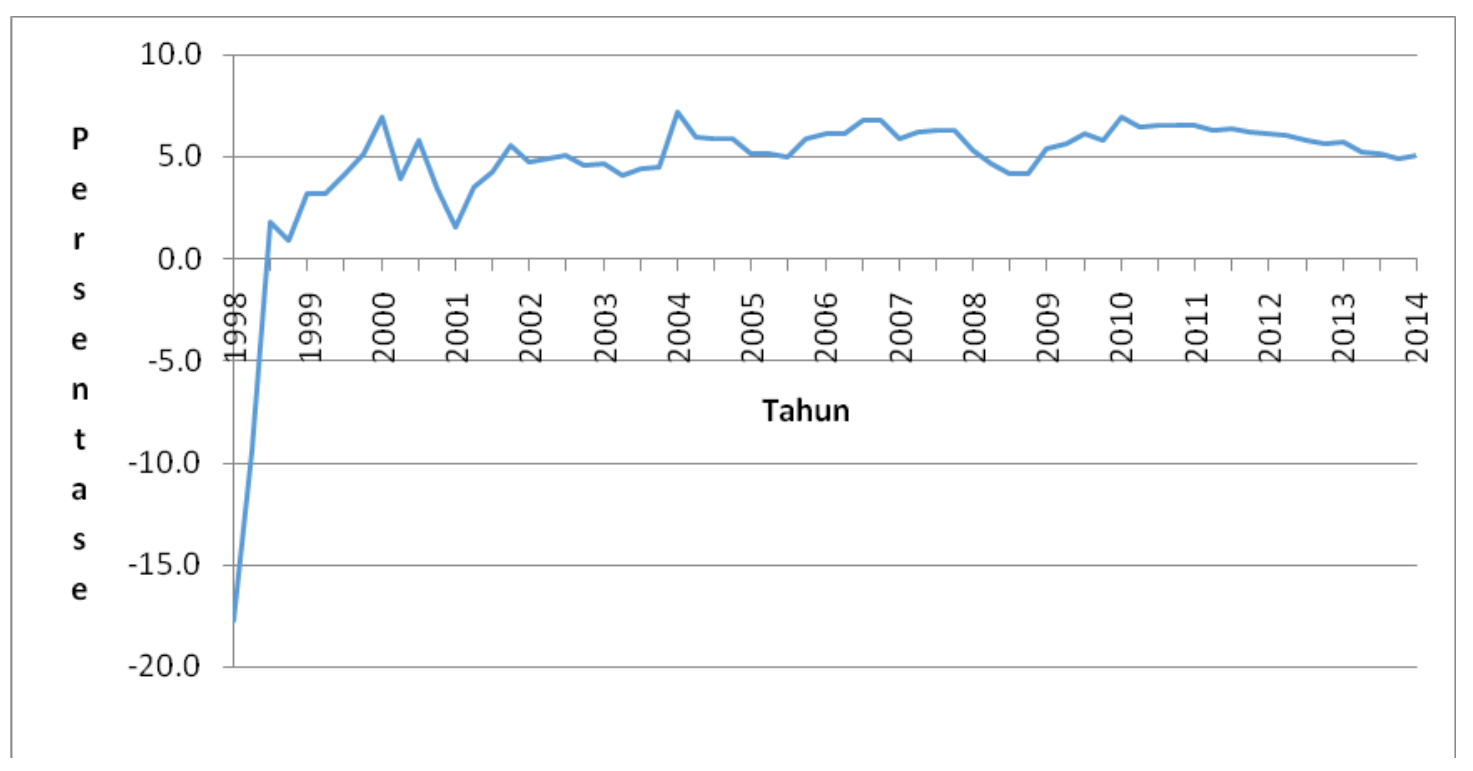


Lampiran 3. Pergerakan Utang Luar Negeri Indonesia dari Triwulan IV Tahun 1998 sampai Triwulan IV Tahun 2014

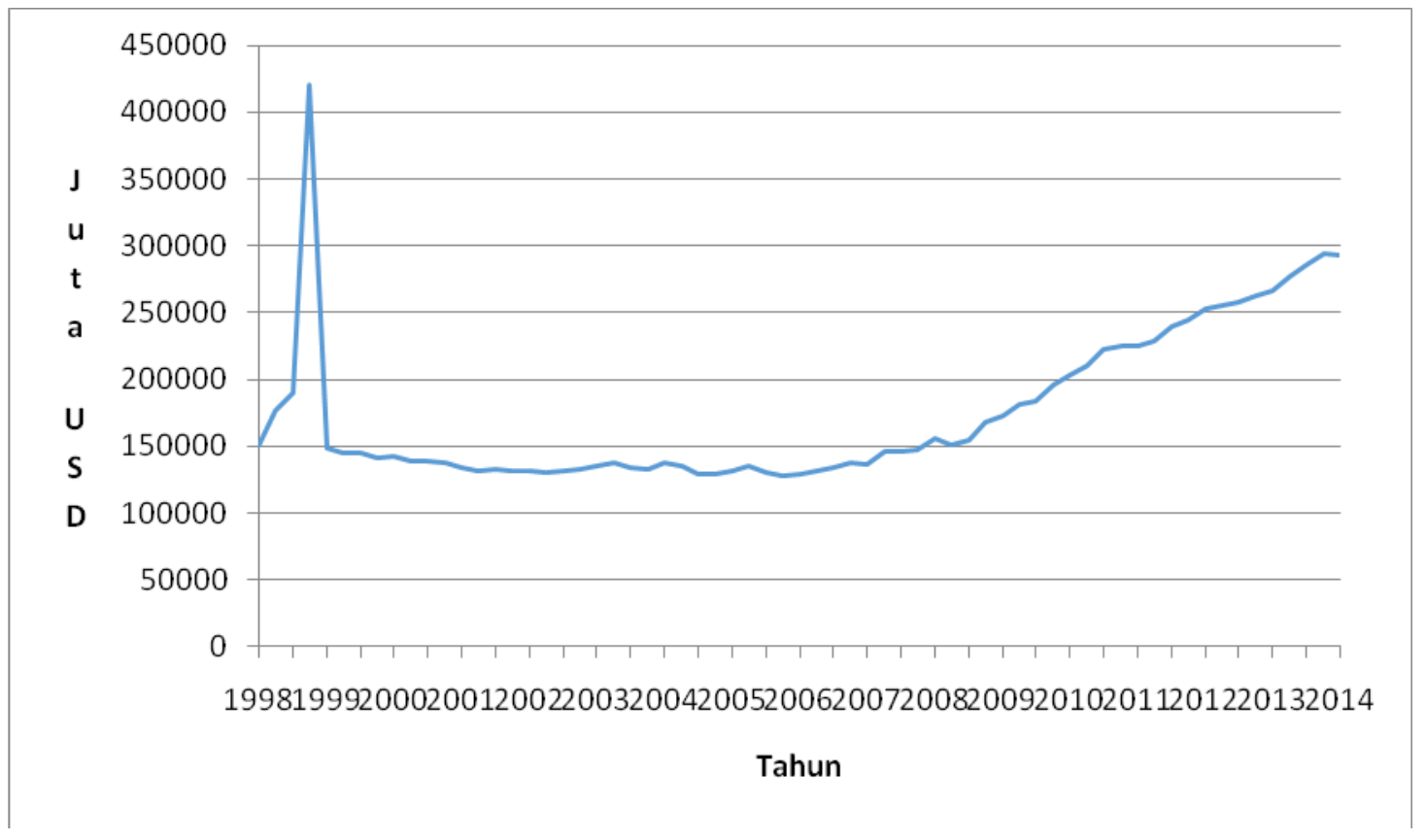

Lampiran 4. Pergerakan Nilai Tukar Rupiah Terhadap USD dari Triwulan IV Tahun 1998 sampai Triwulan IV Tahun 2014

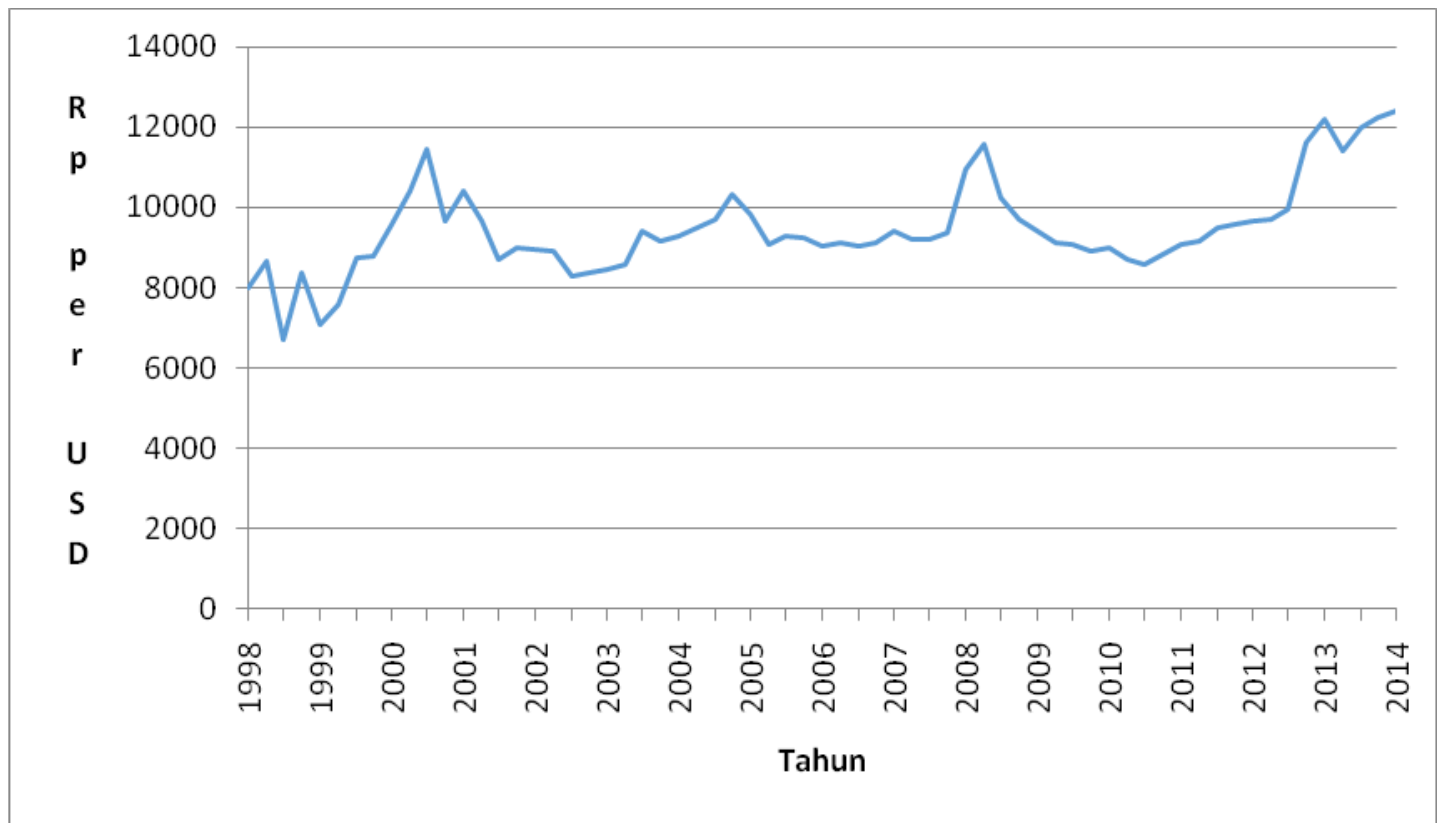


Lampiran 5. Pergerakan Penanaman Modal Asing di Indonesia dari Triwulan IV Tahun 1998 sampai Triwulan IV Tahun 2014

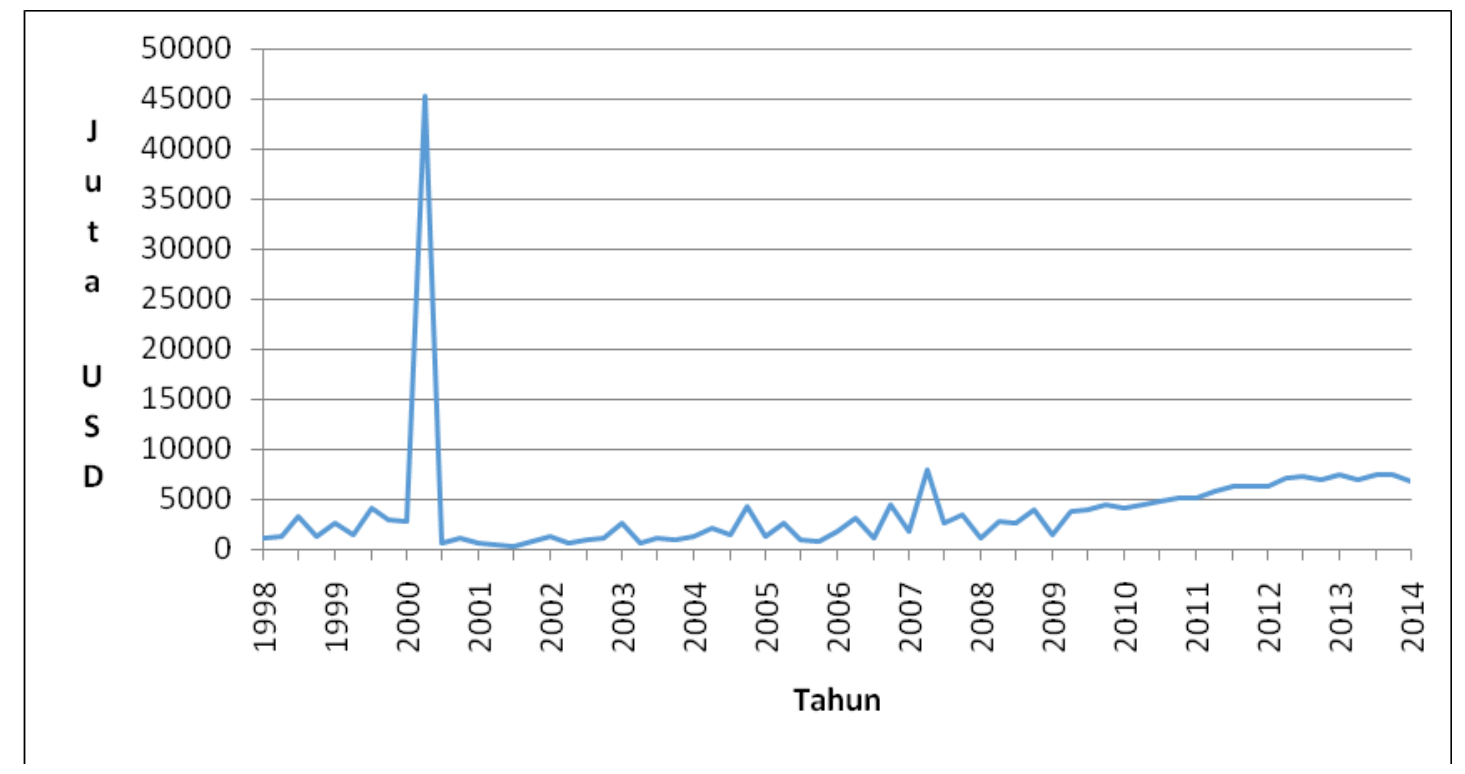

Lampiran 6. Pergerakan Trade Openness Indonesia dari Triwulan IV Tahun 1998 sampai Triwulan IV Tahun 2014

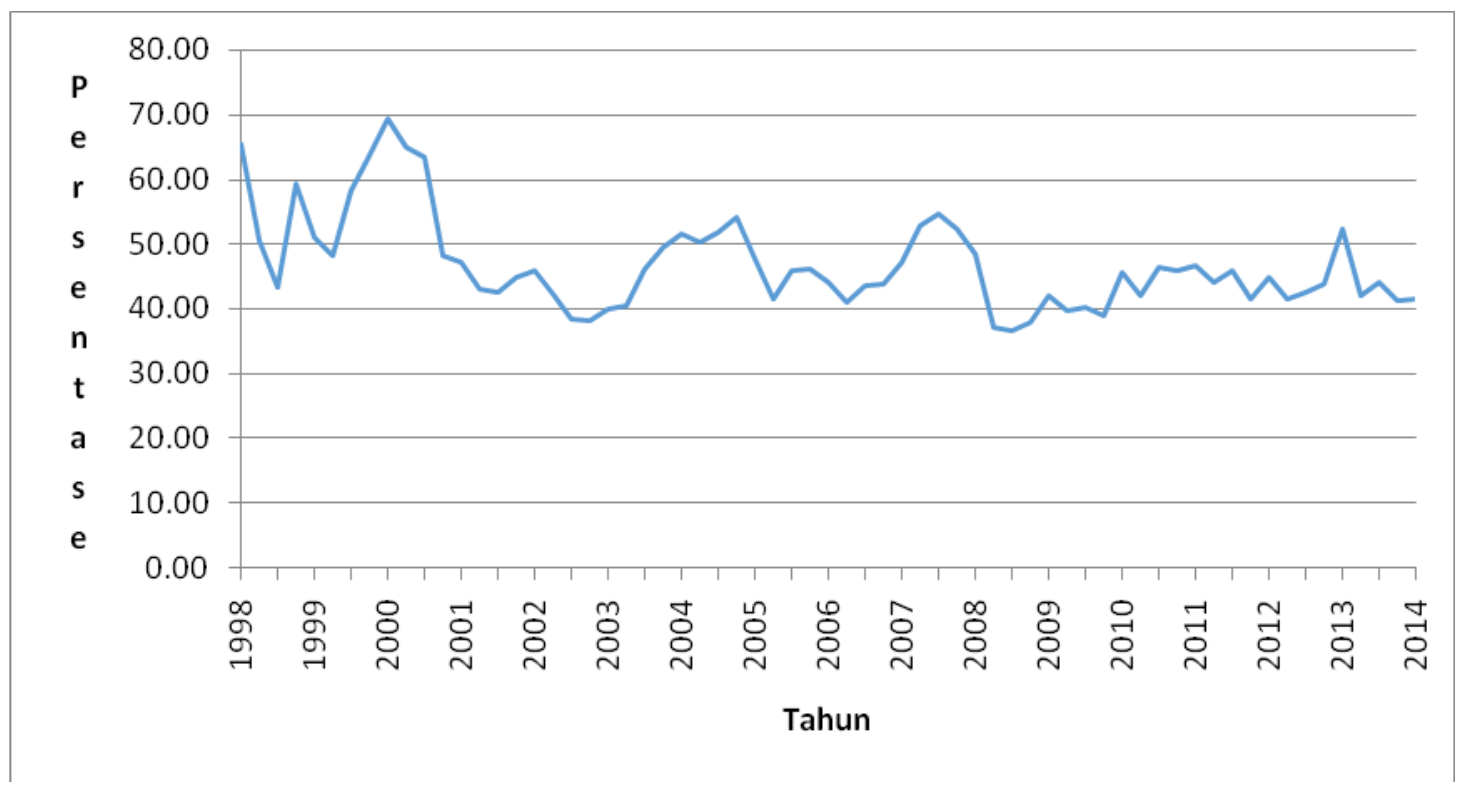




\section{Lampiran 7. Hasil Johansen Cointegration Test}

Date: 08/25/15 Time: 14:37

Sample (adjusted): 365

Included observations: 63 after adjustments

Trend assumption: Linear deterministic trend (restricted)

Series: LN_PDB LN_KURS LN_PMA LN_ULN TO

Lags interval (in first differences): 1 to 1

Unrestricted Cointegration Rank Test (Trace)

\begin{tabular}{ccccc}
\hline \hline $\begin{array}{c}\text { Hypothesized } \\
\text { No. of CE(s) }\end{array}$ & Eigenvalue & $\begin{array}{c}\text { Trace } \\
\text { Statistic }\end{array}$ & $\begin{array}{c}0.05 \\
\text { Critical Value }\end{array}$ & Prob. ${ }^{\star \star}$ \\
\hline \hline None * & 0.508166 & 115.1093 & 88.80380 & 0.0002 \\
At most 1 * & 0.416106 & 70.40364 & 63.87610 & 0.0128 \\
At most 2 & 0.250679 & 36.50735 & 42.91525 & 0.1884 \\
At most 3 & 0.182916 & 18.32628 & 25.87211 & 0.3224 \\
At most 4 & 0.085044 & 5.599420 & 12.51798 & 0.5128 \\
\hline \hline
\end{tabular}

Trace test indicates 2 cointegrating eqn(s) at the 0.05 level

* denotes rejection of the hypothesis at the 0.05 level

** MacKinnon-Haug-Michelis (1999) p-values

Unrestricted Cointegration Rank Test (Maximum Eigenvalue)

\begin{tabular}{ccccc}
\hline \hline $\begin{array}{c}\text { Hypothesized } \\
\text { No. of CE(s) }\end{array}$ & Eigenvalue & $\begin{array}{c}\text { Max-Eigen } \\
\text { Statistic }\end{array}$ & $\begin{array}{c}0.05 \\
\text { Critical Value }\end{array}$ & Prob.** \\
\hline \hline None * & 0.508166 & 44.70563 & 38.33101 & 0.0081 \\
At most 1 * & 0.416106 & 33.89628 & 32.11832 & 0.0300 \\
At most 2 & 0.250679 & 18.18107 & 25.82321 & 0.3635 \\
At most 3 & 0.182916 & 12.72686 & 19.38704 & 0.3506 \\
At most 4 & 0.085044 & 5.599420 & 12.51798 & 0.5128 \\
\hline \hline
\end{tabular}

Max-eigenvalue test indicates 2 cointegrating eqn(s) at the 0.05 level

* denotes rejection of the hypothesis at the 0.05 level

**MacKinnon-Haug-Michelis (1999) p-values

1 Cointegrating Equation(s): $\quad$ Log likelihood $\quad 77.72446$

Normalized cointegrating coefficients (standard error in parentheses)

$\begin{array}{lccccc}\text { LN_PDB } & \text { LN_PMA } & \text { LN_KURS } & \text { LN_ULN } & \text { TO } & \text { @TREND(2) } \\ 1.000000 & -0.002919 & -0.060200 & -0.004752 & 0.002340 & -0.013367 \\ & (0.01695) & (0.07980) & (0.03164) & (0.00142) & (0.00089)\end{array}$


Lampiran 8. Hasil Estimasi Vector Error Correction Model (VECM)

Vector Error Correction Estimates

Date: 08/03/15 Time: 00:54

Sample (adjusted): 365

Included observations: 63 after adjustments

Standard errors in ( ) \& t-statistics in [ ]

\begin{tabular}{|c|c|c|c|c|c|}
\hline Cointegrating Eq: & CointEq1 & CointEq2 & & & \\
\hline LN_PDB(-1) & 1.000000 & 0.000000 & & & \\
\hline LN_KURS(-1) & 0.000000 & 1.000000 & & & \\
\hline LN_PLN(-1) & $\begin{array}{r}-0.043524 \\
(0.03582) \\
{[-1.21496]}\end{array}$ & $\begin{array}{r}-0.791611 \\
(0.25063) \\
{[-3.15845]}\end{array}$ & & & \\
\hline LN_PMA(-1) & $\begin{array}{r}0.040471 \\
(0.01666) \\
{[2.42884]}\end{array}$ & $\begin{array}{c}0.766578 \\
(0.11658) \\
{[6.57559]}\end{array}$ & & & \\
\hline $\mathrm{TO}(-1)$ & $\begin{array}{r}-0.001060 \\
(0.00169) \\
{[-0.62680]}\end{array}$ & $\begin{array}{r}-0.051494 \\
(0.01184) \\
{[-4.35023]}\end{array}$ & & & \\
\hline @TREND(1) & $\begin{array}{r}-0.014973 \\
(0.00077) \\
{[-19.4052]}\end{array}$ & $\begin{array}{r}-0.025871 \\
(0.00540) \\
{[-4.79229]}\end{array}$ & & & \\
\hline C & -12.31451 & -2.344875 & & & \\
\hline Error Correction: & D(LN_PDB) & D(LN_KURS) & $\mathrm{D}\left(\mathrm{LN} \_\mathrm{PLN}\right)$ & $\mathrm{D}\left(\mathrm{LN} \_\mathrm{PMA}\right)$ & $\mathrm{D}(\mathrm{TO})$ \\
\hline CointEq1 & $\begin{array}{r}-0.417915 \\
(0.06617) \\
{[-6.31551]}\end{array}$ & $\begin{array}{c}0.529962 \\
(0.22756) \\
{[2.32893]}\end{array}$ & $\begin{array}{c}0.680327 \\
(0.45452) \\
{[1.49679]}\end{array}$ & $\begin{array}{r}-0.813649 \\
(2.32201) \\
{[-0.35041]}\end{array}$ & $\begin{array}{r}-2.553174 \\
(13.8286) \\
{[-0.18463]}\end{array}$ \\
\hline CointEq2 & $\begin{array}{c}0.032383 \\
(0.00929) \\
{[3.48534]}\end{array}$ & $\begin{array}{r}-0.013354 \\
(0.03195) \\
{[-0.41797]}\end{array}$ & $\begin{array}{r}0.101957 \\
(0.06382) \\
{[1.59760]}\end{array}$ & $\begin{array}{r}-1.190204 \\
(0.32603) \\
{[-3.65060]}\end{array}$ & $\begin{array}{r}3.611914 \\
(1.94165) \\
{[1.86023]}\end{array}$ \\
\hline $\mathrm{D}\left(\mathrm{LN} \_\mathrm{PDB}(-1)\right)$ & $\begin{array}{r}-0.080322 \\
(0.07677) \\
{[-1.04622]}\end{array}$ & $\begin{array}{r}0.266325 \\
(0.26401) \\
{[1.00878]}\end{array}$ & $\begin{array}{r}-0.472282 \\
(0.52733) \\
{[-0.89560]}\end{array}$ & $\begin{array}{r}2.606576 \\
(2.69398) \\
{[0.96756]}\end{array}$ & $\begin{array}{r}58.68393 \\
(16.0438) \\
{[3.65772]}\end{array}$ \\
\hline $\mathrm{D}\left(\mathrm{LN} \_K U R S(-1)\right)$ & $\begin{array}{c}0.008382 \\
(0.03900) \\
{[0.21491]}\end{array}$ & $\begin{array}{r}-0.348240 \\
(0.13412) \\
{[-2.59656]}\end{array}$ & $\begin{array}{r}-0.982307 \\
(0.26789) \\
{[-3.66688]}\end{array}$ & $\begin{array}{r}0.409335 \\
(1.36854) \\
{[0.29910]}\end{array}$ & $\begin{array}{r}-29.06723 \\
(8.15028) \\
{[-3.56641]}\end{array}$ \\
\hline D(LN_PLN(-1)) & $\begin{array}{r}-0.144463 \\
(0.01634) \\
{[-8.84089]}\end{array}$ & $\begin{array}{r}-0.079170 \\
(0.05619) \\
{[-1.40893]}\end{array}$ & $\begin{array}{r}-0.125286 \\
(0.11224) \\
{[-1.11626]}\end{array}$ & $\begin{array}{r}-0.309914 \\
(0.57339) \\
{[-0.54050]}\end{array}$ & $\begin{array}{r}2.470981 \\
(3.41477) \\
{[0.72362]}\end{array}$ \\
\hline $\mathrm{D}\left(\mathrm{LN} \_\mathrm{PMA}(-1)\right)$ & $\begin{array}{r}-0.008170 \\
(0.00422) \\
{[-1.93672]}\end{array}$ & $\begin{array}{c}0.012752 \\
(0.01451) \\
{[0.87900]}\end{array}$ & $\begin{array}{r}-0.045064 \\
(0.02898) \\
{[-1.55516]}\end{array}$ & $\begin{array}{r}-0.096646 \\
(0.14804) \\
{[-0.65286]}\end{array}$ & $\begin{array}{r}0.239783 \\
(0.88161) \\
{[0.27198]}\end{array}$ \\
\hline
\end{tabular}




\begin{tabular}{lrrrrr}
\multicolumn{1}{c}{$\mathrm{D}(\mathrm{TO}(-1))$} & 0.001770 & 0.002526 & -0.003619 & -0.002227 & 0.255996 \\
& $(0.00057)$ & $(0.00197)$ & $(0.00394)$ & $(0.02011)$ & $(0.11978)$ \\
& {$[3.08870]$} & {$[1.28155]$} & {$[-0.91933]$} & {$[-0.11072]$} & {$[2.13717]$} \\
& & & & & \\
& 0.019572 & 0.004882 & 0.023872 & -0.014206 & -0.872532 \\
& $(0.00275)$ & $(0.00947)$ & $(0.01892)$ & $(0.09667)$ & $(0.57572)$ \\
& {$[7.10450]$} & {$[0.51530]$} & {$[1.26156]$} & {$[-0.14695]$} & {$[-1.51555]$} \\
\hline \hline R-squared & 0.717871 & 0.320906 & 0.456400 & 0.542703 & 0.429492 \\
Adj. R-squared & 0.681963 & 0.234475 & 0.387215 & 0.484502 & 0.356881 \\
Sum sq. resids & 0.020457 & 0.241918 & 0.965176 & 25.18972 & 893.4100 \\
S.E. equation & 0.019286 & 0.066321 & 0.132471 & 0.676753 & 4.030362 \\
F-statistic & 19.99230 & 3.712888 & 6.596770 & 9.324569 & 5.915032 \\
Log likelihood & 163.6319 & 85.81901 & 42.23213 & -60.51711 & -172.9283 \\
Akaike AIC & -4.940696 & -2.470445 & -1.086734 & 2.175147 & 5.743756 \\
Schwarz SC & -4.668552 & -2.198301 & -0.814590 & 2.447291 & 6.015900 \\
Mean dependent & 0.015817 & 0.005637 & 0.008054 & 0.027208 & -0.140062 \\
S.D. dependent & 0.034198 & 0.075801 & 0.169226 & 0.942577 & 5.025723 \\
\hline \hline Determinant resid covariance (dof adj.) & $1.20 \mathrm{E}-07$ & & & \\
Determinant resid covariance & $6.06 \mathrm{E}-08$ & & & \\
Log likelihood & & 76.53069 & & & \\
Akaike information criterion & -0.778752 & & & \\
Schwarz criterion & 0.990184 & & & \\
\hline \hline
\end{tabular}

